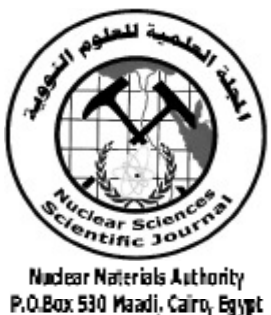

ISSN 2314-5609

Nuclear Sciences Scientific Journal

vol. 4, p 151-162

2015

\title{
A NEW STONY-IRON METEORITE FIND IN KATTAMIYA DESERT, SOUTH EAST CAIRO, EGYPT
}

\author{
ALI A. EL-SOKKARY \\ Nuclear Materials Authority
}

\begin{abstract}
The present study records for the first time are the presence of a meteorite find at Kattamiya Desert lying south east of Cairo by about $25 \mathrm{~km}$ in the Egyptian land. The field of occurrence of the meteorite is well studied. Three big pieces of the meteorite are collected from the location weighing $750 \mathrm{gm}, 1000 \mathrm{gm}$ and $1300 \mathrm{gm}$. These occur beside a lot of many fragments (450 gm weight). The meteorite is assigned to the group of stony-irons meteorites.

The stony surface of the meteorite is dark in color, with lustrous glassy material, full of pits, with a pointed head and concentric flow rings. Moreover the surface represents a molten glassy outer skin. The lower surface of the stone is composed mainly of an iron mineral sometimes in the form of moderate globules. The lower surface takes a brownish color.

Mineralogy of the different objects of the meteorite was studied by x-ray diffraction. This study revealed the presence of the following minerals; kamactie, troilite, pyroxene mineral mostly titanoferroaugite and a calcic plagioclase feldspar. These minerals together characterise a special class of stony-irons group called mesosiderites.

On the other hand, wet quantitative chemical analysis of the stony part of the meteorite revealed high $\mathrm{Al}_{2} \mathrm{O}_{3}, \mathrm{CaO}, \mathrm{MgO}$ and total $\mathrm{Fe}$ contents like Ca-rich achondrites. Therefore, the stony part of Kattamiya meteorite much resembles the Ca-rich achondrites. This places the meteorite find among true meteorites. Thus, the total evidence that comes from field mode of occurrence, hand specimen description, X-ray diffraction of minerals beside chemical analyses of different phases of the find, all point towards a meteorite find belonging to the group of stony-irons or siderolites.

This meteorite find we called El-Kattamiya meteorite or more simply Kattamiya meteorite or Kattamiyite referring to the original place where it was first found.
\end{abstract}

\section{INTRODUCTION}

In the year 1908, a meteorite was observed to fall from the sky in a small village called El-Nakhla or more simply Nakhla, near Abu Hommos town in El-Beheira Governorate, Egypt. This is called Nakhlite or Nakhlites and represents a true meteorite fall. This meteorite fall is regarded as one of 33 meteorites on the whole earth coming from the planet Mars (Google, Meteorites, 2010).
More precisely it comes from the asteroid belt between Mars and Jupiter. This Nakhlites is classified as Ca-rich achondrite (Wedepohl, 1971). According to Heide (1964) Nakhlites is composed of diopside and olivine as principal minerals.

El-Shazly (1958) reported a new meteorite find west of Aswan city, Egypt. Its position is about $30 \mathrm{~km}$ to the west of Aswan on the road between Aswan and Karkour oasis. De- 
tailed analysis of this meteorite find proved it to be composed mainly of kamacite which is an Fe-Ni mineral. The Fe content in this meteorite body is $92 \%$ and $\mathrm{Ni}$ content is $5.96 \%$. El-Shazly (1958) says that the shape of the stone, presence of pits on its surface beside the outer molten skin, all assure its meteorite origin.

El-Sokkary (1986) discovered the present meteorite find in the desert of El Kattamiya, south east Cairo, Egypt, (Fig.1). According to standard nomenclature, this is called Kattamiyite or Kattamiya meteorite find referring to its original site (El-Sokkary, 1986).

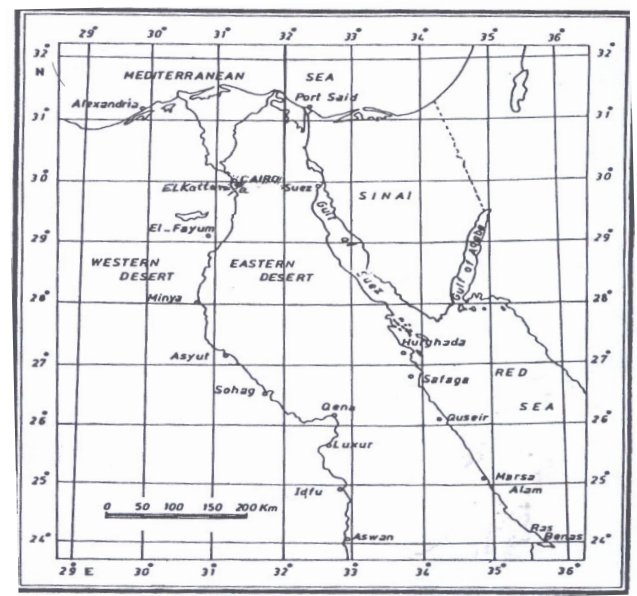

Fig.1:Key map showing the location of the Kattamiya meteorite find

\section{FIELD OF OCCURRENCE}

The Kattamiya meteorite is composed of three main big pieces beside a lot of so many smaller and broken fragments, mostly all with dark color. They all together occupy a field area of about 132 square meters and all weighing about $3.5 \mathrm{~kg}$ (Figs.2 \& 3).

The big pieces are dark or black in color, heavy, containing many pits or voids, with the presence of black glassy lustrous material. This glassy material is sometimes light in weight forming tektite-like small bodies. One of the big pieces weighing $750 \mathrm{gm}$ has a corner like the head of an arrow which may indicate the direction of fall. The same piece has so many concentric circular lines indicating the effect of air currents on semi-molten material during falling. The current lines have their convex side towards the arrow's head, (Fig.4).

Some of the big pieces of the meteorite find contain both stone and iron material. Therefore, this meteorite belongs to a smaller group of meteorites known as stony-irons, siderolites or lithosiderites (Wedepohl,1971). Since this meteorite material is not observed to fall from the sky in front of any person, rather it is found as it is on the surface of the wadi floor. Thus it does not represent a meteorite fall, but it represents a meteorite find.

It is to be noted that meteorite pieces are found on surface of wadi floor not in pits or

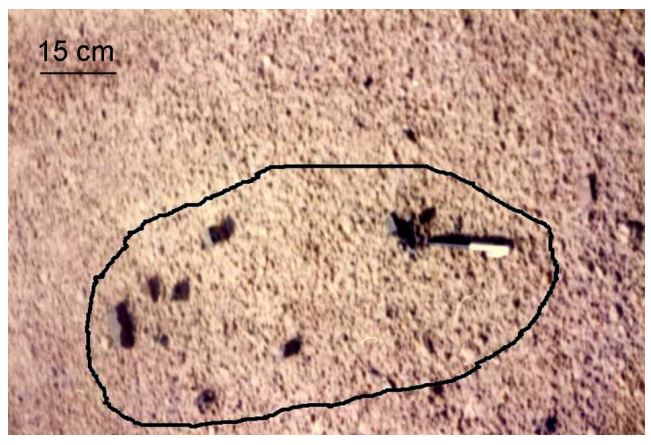

Fig.2:The occurrence field of Kattamiya meteorite in the desert of El Kattamiya. The main field of occurrence is about $132 \mathrm{~m}^{2}$

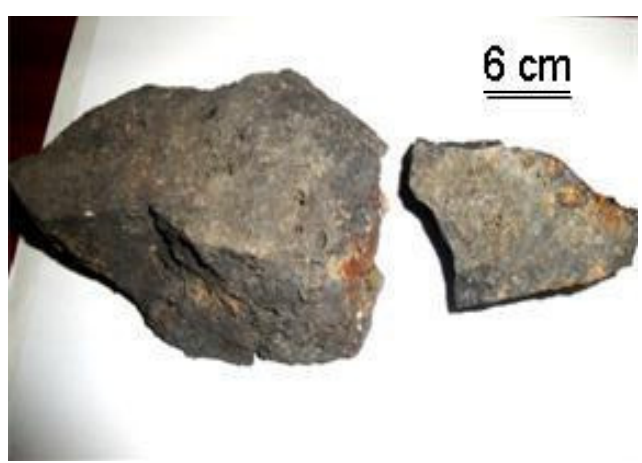

Fig.3: Two of the three main big pieces of the meteorite find 


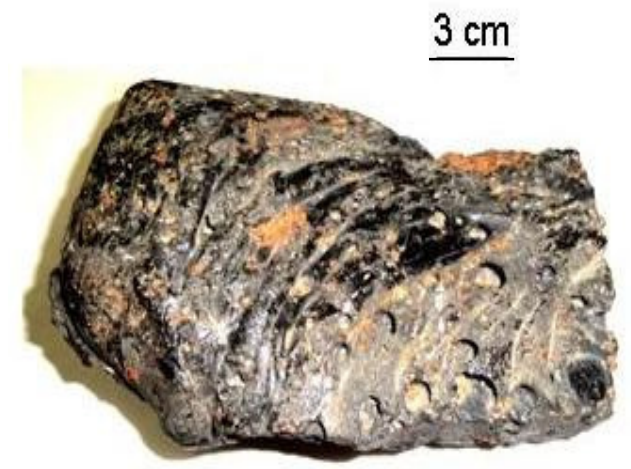

Fig.4: Note the presence of many flow circular concentric lines on the stony surface of the meteorite

holes whether shallow or deep. The wadi floor is composed of loose sands and gravels with yellow color and much lime or carbonate material. Meteorite fragments are black in color making contrast with the yellow wadi sediments.

According to Wedepohl (1971), stony-iron meteorites constitute only 2 percent of all meteorites and are relatively rare. Therefore, Kattamiya meteorite is a rare one and deserves much more attention and much more analyses

The same author, Wedepohl (1971), classified the group of stony-irons into four classes: pallasites, siderophyres, lodranites, and mesosiderites. The mesosiderites have their major minerals: orthopyroxene, plagioclase, kamactite, taenite and troilite. On the basis of mineralogical analysis of Kattamiya meteorite find by X-ray diffraction method, it is concluded that it belongs to the class of mesosiderites because it is composed mineralogically of pyroxene, plagioclase, kamacite and troilite.

\section{HAND SPECIMEN DESCRIPTION}

As already mentioned, three main big pieces of Kattamiya meteorite were found in the field of occurrence. These weight $750 \mathrm{gm}$, $1000 \mathrm{gm}$ and $1300 \mathrm{gm}$ respectively. These are accompanied by a lot of fragments of different shapes, sizes, colors and minerals weighting
$450 \mathrm{gm}$. Thus, the total weight of meteorite material is $750+1000+1300+450=3500$ $\mathrm{gm}=3.5 \mathrm{~kg}$. Among these pieces and fragments, eight different hand specimens could be distinguished in the filed. The description of these specimens is as follows:

\section{The Stone-Iron Meteorite}

The big piece to be described here is the one that weighs $750 \mathrm{gm}$ and has the dimensions: $14 \times 10 \times 3 \mathrm{~cm}$. It takes nearly the shape of a rectangle, (Figs. $4 \& 5$ ). The upper face is almost stony with a molten bright glass skin. It has a dark or black color. It is full of pits or voids that are empty. The average diameter of these pits is about $5 \mathrm{~mm}$ based on ten measurements. It contains parts that are lustrous. One of the corners of the rectangle takes the shape of the head of an arrow. Ten concentric rings or flow lines are present on this surface with the convex side facing the arrow's head, (Fig.4).

The lower surface of the find stone is composed mainly of an iron mineral mostly kamacite, sometimes in the form of moderate globules $6 \mathrm{~mm}$ wide. The lower surface takes a brownish color on account of the presence of rust of iron in the form of the mineral goethite which is hydrated iron oxides. This rust is thought to be happened after the meteorite reached the earth.

To sum up, the stony surface of the meteor-

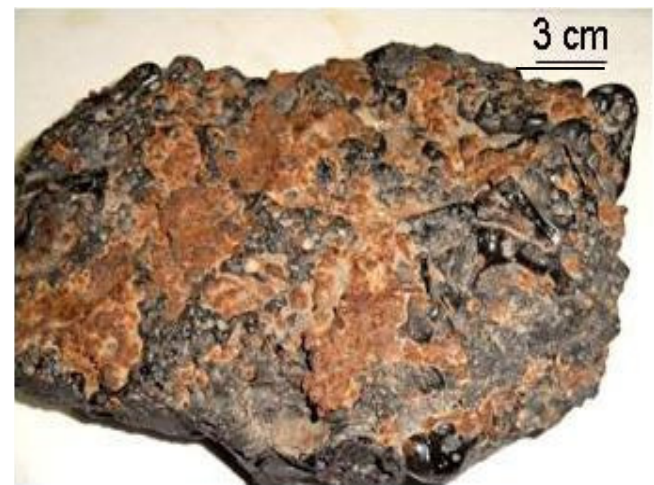

Fig.5:One of the three big pierces of the meteorite, it weights $750 \mathrm{~g}$ 
ite is dark in color with lustrous glassy material, full of pits, with a pointed head like arrow's head and concentric flow marks. Moreover, this surface represents a molten glassy outer skin.

The arrow's head indicates the direction of fall of the stone, while the flow lines with concentric arcs show that the stone was projected in air with high velocity in a semimolten state.

Thus the criteria from color, pits, lustrous glassy material, flow lines, heavy specific gravity, presence of stone and iron phases, all indicate that we are in front of a meteorite fall. The author called it Kattamiya meteorite or simply Kattamiyite.

\section{The Black Glass Lustrous Material}

This material is present as irregular broken fragments with variable sizes ranging from $30-40 \mathrm{~mm}$ (Fig.6A, B \& C). The material is black in color, glassy, lustrous, sometimes heavy, with pitted surface and the presence of traces of rust iron. In sunlight, some specimens develop yellowish-green or olive green color. This material is mainly stony meteorite being composed of Fe-Mg silicates i.e. clinopyroxene mineral.

\section{Tektite-Like Material}

The material has light specific gravity and pale reddish tints. It may be the result of melting and solidification of the country rock as a result of the tremendous heat (around $2000^{\circ} \mathrm{C}$ ) accompanying the fall impact of the meteorite. It might be contaminated with some of the original meteorite material like iron.

Mason (1964) says that tektites consist of a silica-rich glass (average about $70 \% \mathrm{SiO}_{2}$ ) resembling obsidian yet distinct from any terrestrial obsidian. Thus the percentage of $\mathrm{SiO}_{2}$ in the present Kattamiya tektites is important in determining its nature.

\section{The Long Iron Drops}

This rusty $\mathrm{Fe}$ material takes the form of long drops, (Fig.7), globules and irregular frag-

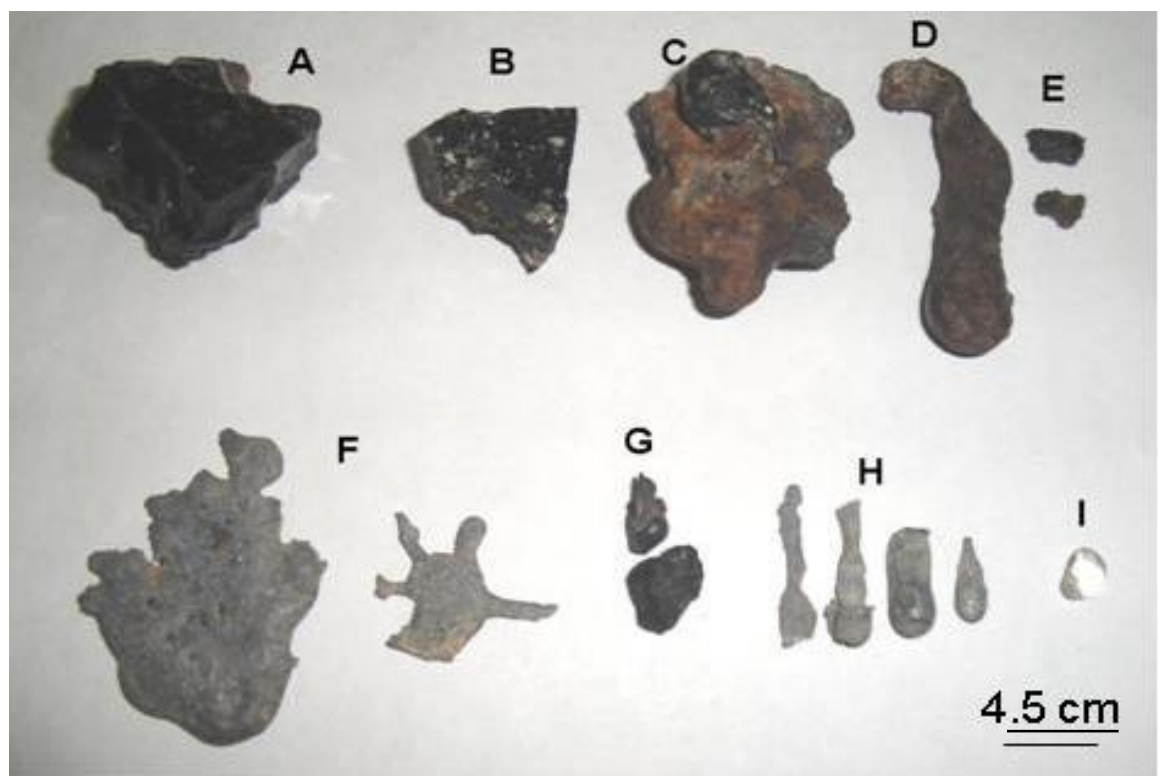

Fig.6: A collective photo of many portions of the Kattamiya meteorite

(A, B, C) Dark colored glasses,(D) Long iron droplet, which is rusty,E) Two iron globules , (F) Two skeletal grayish white material ,(G) A small piece of coal, (H) Four long grayish white drops and droplets, (I) A pure transparent quartz globule. 
ments. One of these drops is $5 \mathrm{~cm}$ in length and being stout. The globules are $6 \mathrm{~mm}$ in diameter and even lesser. The iron is covered by a thin layer of brownish rust of goethite mineral with chemical formula $\mathrm{Fe}_{2} \mathrm{O}_{3} \cdot \mathrm{H}_{2} \mathrm{O}$. This iron is magnetic. Some of the drops, droplets and globules fill the pitted surface of the stony material. On rubbing the rusty iron with sandpaper, fresh iron appears.

\section{The White Long Drops}

This takes the following shapes: bar-like, long drops, droplets, skeletal and irregular shapes, (Figs.8, 9, 10, $11 \& 12$ ). Some of the bars are $5-6 \mathrm{~cm}$ in length. It is clear that all the shapes particularly the long drops and droplets are the result of melting and subsequent solidification. The long droplets strongly look like tin (Sn) bars.

The material is grayish white in color but covered with thin dull oxidized layer which can be removed by rubbing with sandpaper after witch a silvery white lustrous surface appears. This material according to Dana (1949) may be the mineral cohenite $(\mathrm{Fe}, \mathrm{Ni}, \mathrm{Co})_{3} \mathrm{C}$ which appears in tin-white crystals.

\section{Colorless Silica Glass}

It is present as one drop or globule of clear colorless transparent silica glass of about 8

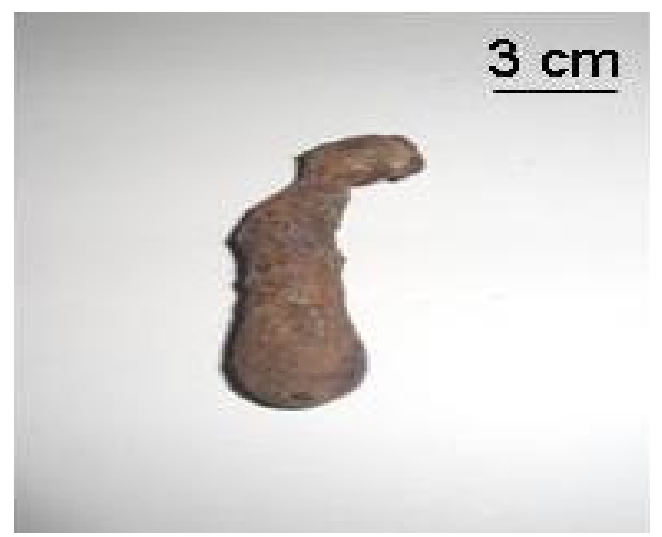

Fig.7: A single drop of metallic iron. The drop is rusted with brownish hydrated iron oxides

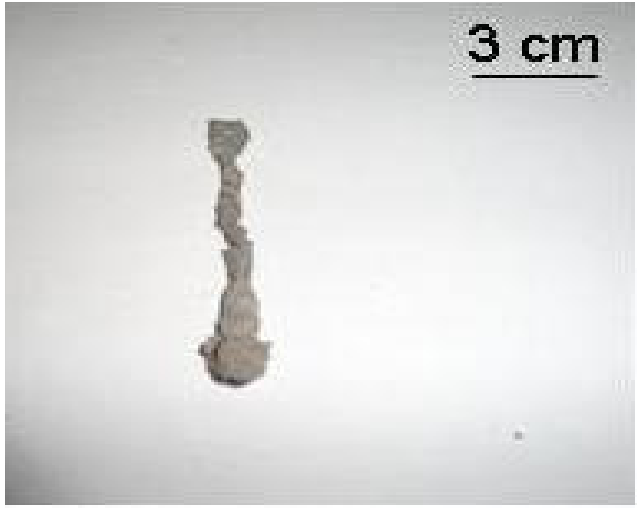

Fig.8: One of the long drops or bars of grayish white color

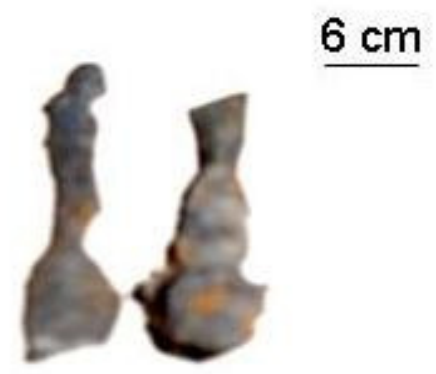

Fig.9: A long white silvery drop accompanying the material of the meteorite find. The drop looks like Sn metal

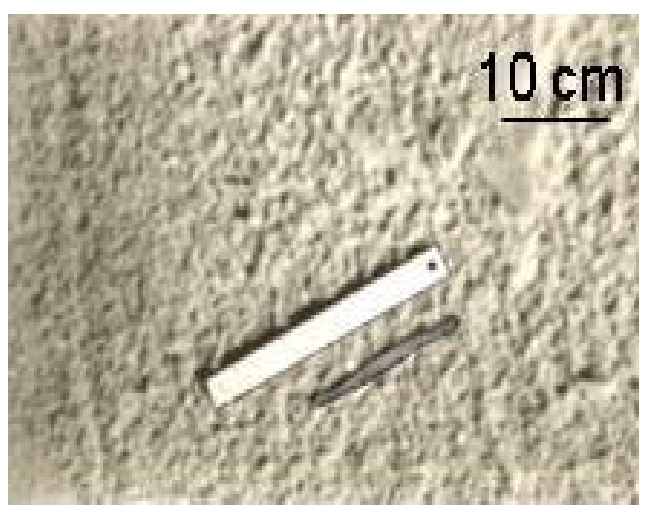

Fig.10: Another piece of the long white drop taken to scale by a ruler 


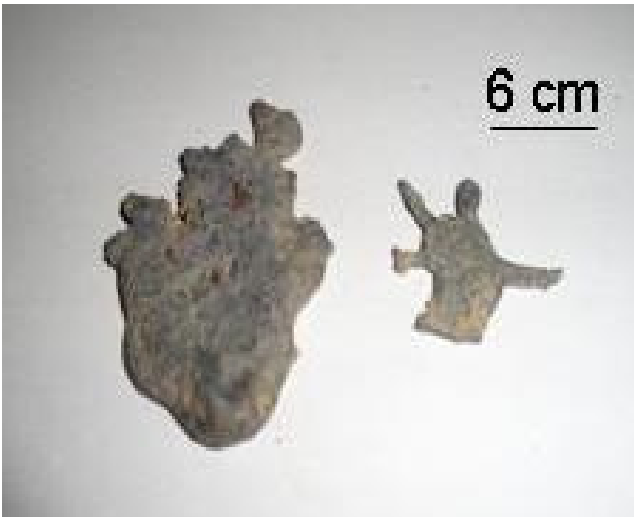

Fig.11: A skeletal piece of the grayish white material of Kattamiya meteorite

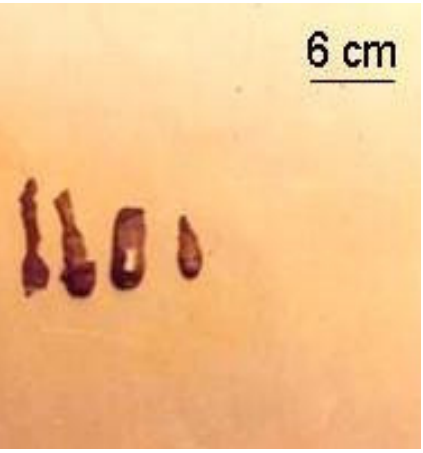

Fig.12: Four long white drops indicating definite melting and solidification of this material

$\mathrm{mm}$ in diameter (Fig.12I). This is probably formed as the result of fusion of pure sands in contact with the impact site of the falling hot meteorite. The source of sands in this case comes from wadi floor on which the meteorite settled. Nevertheless, it might be part of the original mineral constitution of the meteorite find. This silica drop might belong to high temperature silica minerals like cristobalite $\left(275^{\circ} \mathrm{C}\right)$ and tridymite $\left(800^{\circ} \mathrm{C}\right)$.

\section{Coal Piece}

This material is black in color, light in specific gravity, and quite porous. It is in the form of one piece only, being small in size (Fig.12G). This carbonaceous piece can be used in dating the fall of the meteorite event.

\section{The Rust of Iron Material}

The rusty material is yellowish-brown in color, (Fig.12D). It stains most of the iron material of the meteorite. It is often composed of the mineral goethite with a chemical formula: $\mathrm{Fe}_{2} \mathrm{O}_{3} \cdot \mathrm{H}_{2} \mathrm{O}$. This rust mostly happened on earth after the meteorite fall by atmospheric humidity or by the effect of rain water and oxygen. The rust material can be removed by sandpaper, where fresh metallic iron appears.

\section{MINERALOGY AND CHEMISTRY OF THE DIFFERENT METEORITE PHASES}

Three main phases or parts of Kattamiya meteorite are subjected here to both mineralogical and chemical analysis. These phases are: the stony portion, the iron or siderite portion and the grayish white long drops. The mineralogy of these phases is studied mainly by X-ray diffraction. Wet quantitative chemical analysis is carried out on the same three portions of the meteorite material. Hereafter are the main results of the above mentioned analyses.

\section{X-Ray Diffraction of the Stony Material}

The stony part of Kattamiya meteorite represented by sample KM-1 which is identified as stone material of the meteorite was X-rayed and gave these main lines: 4.23(20)-4.00(50)3.33(100).

The four important lines of standard augite with ASTM card No.3-0623 are: 2.99(100)1.62(100)-1.43(100)-3.31(50). The last line of the standard card, namely 331 (50), is actually the third line that appears in the sample diffraction pattern 3-33 (100).

Note that intensities of lines may be variable with different augites and with different radiations. Note also that the chemical composition of this standard augite is $(\mathrm{Ca}, \mathrm{Fe}$, $\mathrm{Mg}) \mathrm{SiO}_{3}$ which might account for most of the chemical composition of the analyzed stony meteorite sample.

Standard hypersthene on the other hand 
with ASTM card No.2-0520 gives the following important lines: 3.20(100)-2.89(80)1.49(80)-3.36(30).

The chemical composition of this standard mineral: (Mg, Fe)O. $\mathrm{SiO}_{2}$ cannot account for the chemical analysis of the given stone meteorite.

On the other hand, line 4.00 (50) of the sample may conform with line 4.02(80) of high oligoclase with ASTM card No.9-456 or with line 4.03(80) of bytownite with ASTM card No.9-467. Both minerals are members of the calcic plagioclase series.

Therefore and on the basis of X-ray diffraction alone, the stony part of Kattamiya meteorite is composed mainly of the mineral augite which is a member of the pyroxene group beside a possible member of the calcic plagioclases (bytownite).

It is to be noted that line 4.02-4.04 is present nearly in all the plagioclase feldspar members but with varying intensities from 16-80. Wedepohl (1971) during his classification of meteorite minerals assigned plagioclases with $5-10 \%$ as oligoclase in chondrites but in achondrites the plagioclase is usually bytownite. Since the stony part of the studied Kattamiya meteorite much resembles Ca-rich achodrites, it is possible that the plagioclase feldspar is bytownite.

\section{Chemical Analysis of The Stony Material}

The stony phase is represented here by meteorite sample number 7 from Kattamiya site and is identified as black glassy material. Table (1) gives a comparison of quantitative chemical analysis data of the black glassy material with $\mathrm{Ca}$-rich achondrites.

On the other hand, Table (2) shows a comparison of the chemical analyses of samples with numbers 5 and 7 which represent stony material and black glassy material of the meteorite respectively with the corresponding analyses of two varieties of ferroaugite (pyroxene) and calcic plagioclase which is labradorite. The analyses of ferroaugites and
Table 1: Comparison of chemical analyses (wt. \%) of meteorite sample No.7 with Ca-rich achondrite

\begin{tabular}{lrr}
\hline Oxide & S. No. $7^{*}$ & Ca-rich Achond. ${ }^{* *}$ \\
\hline $\mathrm{SiO}_{2}$ & 52.82 & 48.65 \\
$\mathrm{Al}_{2} \mathrm{O}_{3}$ & 9.40 & 11.71 \\
$\mathrm{Na}_{2} \mathrm{O}$ & 0.51 & 0.83 \\
$\mathrm{~K}_{2} \mathrm{O}$ & 1.03 & 0.27 \\
$\mathrm{CaO}$ & 15.71 & 10.39 \\
$\mathrm{MgO}$ & 5.65 & 9.87 \\
$\mathrm{Fe}_{2} \mathrm{O}_{3}{ }^{\text {t }}$ & 12.78 & 16.31 \\
$\mathrm{MnO}$ & 0.06 & 0.47 \\
$\mathrm{P}_{2} \mathrm{O}_{5}$ & 0.23 & 0.10 \\
$\mathrm{TiO}_{2}$ & 1.41 & 0.50 \\
$\mathrm{Cr}_{2} \mathrm{O}_{3}$ & - & 0.40 \\
$\mathrm{Total}$ & 99.60 & 99.50 \\
\hline "Meteorite S. No. 7 = Black glassy material, & *** Data according to Urey and Craig, (1953)
\end{tabular}

lobradorite are taken from Deer et al., (1972).

Results of comparisons of Table (2) revealed that the stone part of Kattamiya meteorite is composed of titanoferroaugite plus a calcic plagioclase feldspar mostly in the form of an antiperthite.

Sample No.7 which is black glassy material has high $\mathrm{Al}_{2} \mathrm{O}_{3}, \mathrm{CaO}, \mathrm{MgO}$ and total $\mathrm{Fe}_{2} \mathrm{O}_{3}$ contents like $\mathrm{Ca}$-rich achondrites, besides it has similar value to this achondrite with respect to $\mathrm{SiO}_{2}$. Therefore, sample No.7 is Carich achondrite. This means that the material under analysis is definitely as a meteorite.

\section{Mineralogy and Chemistry of the Siderite Part}

Sample KM-3 is an Fe globule which represents the siderite portion of Kattamiya meteorite. It is analyzed by X-ray diffraction to determine its mineralogy as follows. This sample gave the following main lines: $3.33(30)-$ 2.02(100)-1.43(?). This conforms with the mineral kamacite which is alpha Fe.Ni.

The siderite part of this meteorite find is analyzed chemically from a quantitative point of view. Sample No.6 is identified here as iron material. It gave the following analyses (Table 
Table 2: Comparison of chemical analyses (wt. \%) of some ferroaugites and labradorite with those of the analyses of the stony part of the Kattamiya meteorite

\begin{tabular}{|c|c|c|c|c|c|}
\hline Oxide & Ferroaug. & $\begin{array}{l}\text { Sub-calcic } \\
\text { Ferroaug. }\end{array}$ & S. No.5* & $\begin{array}{r}\text { Labrado- } \\
\text { rite }\end{array}$ & S. No. $7 * *$ \\
\hline $\mathrm{SiO}_{2}$ & 46.61 & 48.90 & 53.63 & 52.96 & 52.82 \\
\hline $\mathrm{TiO}_{2}$ & 1.18 & 0.12 & 1.97 & tr. & 1.41 \\
\hline $\mathbf{A l}_{2} \mathbf{O}_{3}$ & 3.47 & 3.86 & 16.92 & 29.72 & 9.40 \\
\hline $\mathrm{Fe}_{2} \mathrm{O}_{3}$ & 0.90 & 4.65 & - & 0.84 & - \\
\hline $\mathrm{Cr}_{2} \mathrm{O}_{3}$ & - & - & - & - & - \\
\hline FeO & 20.18 & 25.35 & T 7.99 & - & T 12.78 \\
\hline MnO & 1.11 & 0.51 & 0.12 & - & 0.06 \\
\hline $\mathrm{NiO}$ & - & - & - & - & - \\
\hline MgO & 7.27 & 6.87 & 5.25 & - & 5.65 \\
\hline $\mathrm{CaO}$ & 17.24 & 7.96 & 3.37 & 12.28 & 15.71 \\
\hline $\mathrm{Na}_{2} \mathrm{O}$ & 1.04 & 0.58 & 5.06 & 4.21 & 0.51 \\
\hline $\mathbf{K}_{2} \mathbf{O}$ & 0.27 & 0.20 & 3.09 & 0.13 & 1.03 \\
\hline $\mathbf{P}_{2} \mathbf{O}_{5}$ & - & - & 0.06 & - & 0.23 \\
\hline $\mathbf{H}_{2} \mathbf{O}^{+}$ & 0.42 & 0.57 & - & 0.08 & - \\
\hline $\mathbf{H}_{2} \mathrm{O}^{-}$ & 0,04 & 0.36 & - & - & - \\
\hline Total & 99.73 & 99.92 & 97.46 & 100.22 & 99.60 \\
\hline
\end{tabular}

3 ) in weight percent of the oxide or metal.

From X-ray diffraction and chemical analyses, it can be inferred that the Fe material is the mineral kamacite characteristic for siderites. Nevertheless, its Ni content appears to be low.

\section{Mineralogy and Chemistry of the Grayish - White Long Droplets}

X-ray diffraction pattern of the gray-white long droplets (sample No.KM-2) is compared with the X-ray diffraction pattern of troilite with ASTM card No.4-0832 and cohenite with ASTM card No.23-1113. The comparison reveals the presence of both the minerals troilite $(\mathrm{FeS})$ and cohenite $\left(\mathrm{Fe}_{3} \mathrm{C}\right)$.

Cohenite ASTM card No.23-1113 which is iron carbide $\left(\mathrm{Fe}_{3} \mathrm{C}\right)$ has the following four important lines: 2.01(100)-2.06(70)-2.38(65)2.54(6). All of these lines are present in the Xray diffraction pattern of sample KM-2. Similarly the four impotant lines of troilite (FeS) with ASTM card No.4-0832 are: 2.09 (100) -2.98 (90) -2.67 (90)-2.98 (90). Again these lines are all present in the diffraction pattern of the analyzed sample. Therefore, the whitegray long droplets are composed of both troilite plus the mineral cohenite.

Table 3: Chemical analyses (wt. \%) of the siderite portion of Kattamiya meteorite

\begin{tabular}{lr}
\hline Oxide & $\%$ \\
\hline Fe $_{2} \mathbf{O}_{3}{ }^{\mathbf{t}}$ & 39.93 \\
I.R. ${ }^{*}$ & $\mathbf{3 0 . 0 0}$ \\
V.C. *** & $\mathbf{3 0 . 0 0}$ \\
Ni & $\mathbf{0 . 2 1}$ \\
Co & $\mathbf{0 . 2 0}$ \\
Pb & $\mathbf{n . d}$ \\
Total & $\mathbf{1 0 0 . 3 4}$ \\
\hline I.R.: Insoluble residue, ${ }^{* *}$ V.C.: Volatile component \\
which is either S or C or both, n.d: Not detected.
\end{tabular}




\section{Chemistry of the Long Silver - White Droplets}

This meteorite material is chemically analyzed and gives the following data shown in Table (4).

The analyses of this sample raise more questions than answers. But they represent the only available chemical data for this material.

Thus chemical analysis of the long silver white droplets shows that they are composed of major Fe beside minor amounts of both $\mathrm{Pb}$ $(0.4 \%)$ and $\mathrm{Ni}(0.2 \%)$, Co is not detected. The major Fe may form troilite mineral phase plus cohenite mineral phase. The latter mineral cohenite is $(\mathrm{Fe}, \mathrm{Ni}, \mathrm{Co})_{3} \mathrm{C}$. X-ray diffraction analysis shows the presence of troilite which is $\mathrm{FeS}$ and cohenite which is $(\mathrm{Fe}, \mathrm{Ni}, \mathrm{Co})_{3} \mathrm{C}$, Thus the white gray long droplets are composed mineralogically of both troilite and cohenite.

\section{RADIOACTIVITY}

Three main phases of Kattamiya meteorite, namely: siderite phase, stony or silicate phase and troilite (Fe sulfide) phase are subjected to measure their radioactivity by means of a scntillometer. The three phases under study gave radioactivity near the background reading. This means that the content of $\mathrm{U}, \mathrm{Ra}$ and $\mathrm{Th}$ in each of the three phases is below the detection limit of the scintillometer.

Heide (1964) in his book on meteorites and

Table 4: Available chemical analysis of the white long droplets

\begin{tabular}{lc}
\hline Oxide & $\%$ \\
\hline $\mathrm{Fe}_{2} \mathrm{O}_{3}{ }^{\mathrm{t}}$ & 2.87 \\
$\mathrm{~Pb}$ & 0.40 \\
$\mathrm{Ni}$ & 0.20 \\
$\mathrm{Co}$ & n.d \\
\hline n.d: not detected &
\end{tabular}

during a discussion on the chemical constitution of meteorites, referred to the presence of $\mathrm{U}$ and $\mathrm{Th}$ in these heavenly bodies. He says that even such rare elements as uranium and thorium have been determined by neutron activation analysis. In the following Table (5), their abundances in meteoritic irons are compared with those in stone meteorites and terrestrial igneous rocks. All abundances are expressed in units of grams per ton i.e. parts per million.

It is seen from this table that both elements are several orders of magnitude more abundant in stone meteorites than in irons, but that their level in igneous rocks is more than two orders of magnitude higher still than in stone meteorites.

\section{DISCUSSION}

Kattamiyite or Kattamiya meteorite is a meteorite find located in Kattamiya Desert, south east Cairo, Egypt. This material is char-

Table 5: The elements $U$ and Th contents in some meteorites, After Heide, 1964

\begin{tabular}{lrr}
\hline Item & $U(g / t)$ & $T h(g / t)$ \\
\hline Irons & $10^{-3}-10^{-6}$ & $10^{-3}-10^{-6}$ \\
Stones & 0.01 & 0.04 \\
Basic igneous rocks & 1.1 & 3.9 \\
Acidic igneous rocks & 4.1 & 13.0 \\
\hline
\end{tabular}

acterized by dark or black color, shiny glassy material, the surface is pitted with the presence of concentric flow lines. The surface is covered by a molten glassy outer skin. The lower surface of the stone is composed of metallic iron frequently in the form of globules. Many dark colored glass pieces are found in the location, beside an iron drop of $5 \mathrm{~cm}$ length. So many long grayish-white drops are found in the site. Beside a clear quartz bead and a small piece of porous carbon. 
These criteria including the dark color, pitted surface, glassy skin , heavy weight, concentric flow rings, iron globules, beside lustrous dark material, iron drops and grayish white long drops (troilite and cohenite) all indicate that the material under study represents a true meteorite find. This is further confirmed from mineralogical and chemical analyses.

$\mathrm{X}$-ray diffraction analysis of the minerals of Kattamiya material showed that the following minerals are present: kamacite, troilite, cohenite, titanoaugite beside a calcic plagioclase feldspar. This mineral association refers the meteorite find to mesosiderites which is a fourth class of the stony-irons group. Chemical analysis of the meteorite material revealed that the stony part of the meteorite much resembles Ca-rich achondrites.

No body has observed this meteorite material while falling from the sky. Therefore, it is recorded as a meteorite find. Nevertheless, it is recognized now as a meteorite.

Thus the meteorite find is identified here as stony-iron meteorite that belongs to the class of mesosideriles. Moreover, the stony half of the meteorite belongs to the $\mathrm{Ca}$ - rich achondrites.

It is known that iron metal melts at $1535^{\circ} \mathrm{C}$ and boils at $3000^{\circ} \mathrm{C}$. Therefore, the formation of a long drop of iron with $5 \mathrm{~cm}$ length means that the temperature of the meteorite material has reached at least to more than $1500^{\circ} \mathrm{C}$ during fall.

It is to be noted that more mineral and chemical analyses are needed beside studies of the Fe phase under the ore microscope and etching the iron surface. This might give more details that will explain the final origin of the meteorite.

Accurate chemical analyses are needed. The analyses should cover the different meteorite phases including: stony material, iron material, dark glass material, long iron drops and the long grayish white drops beside the transparent quartz bead and the coal material.
Age dating of the last material will give the correct date of the meteorite fall event.

\section{CONCLUSIONS}

A meteorite find is located at Kattamiya Desert, $25 \mathrm{~km}$ south east of Cairo, Egypt. This has the following properties.

1- It is dark in color with pitted surface, glassy skin, heavy weight and many lustrous fragments. It contains iron metal mostly in the form of moderate globules.

2- Mega textures and structures on the surface of the falling stone show the presence of flow lines in the form of concentric rings with a pointed head. This means that the stone was falling from the sky in a semimolten manner with a great velocity. This assures also that the stone comes from the sky.

3- This material is identified as stony - iron meteorite.

4- It belongs to the class of mesosiderites of the siderolites group.

5- It is characterized by the mineral association: pyroxene (augite) - calcic plagioclase - kamacite - troilite - cohenite.

6- The stony portion of the meteorite find is related to $\mathrm{Ca}$-rich achondrites.

7- This meteorite find is called Kattamiya meteorite or Kattamiyite.

8- The meteorite has attained a temperature of more than $1500^{\circ} \mathrm{C}$.

9- It needs more mineralogical and chemical analyses and more detailed studies.

10- The carbon piece found in association with the meteorite material can be used in dating the meteorite fall impact.

Finally, all the above mentioned evidences assure that we are in front of a meteorite find. The field of occurrence should be surveyed several times for finding more meteorite material and meteoritic fragments. 


\section{REFERENCES}

ASTM Cards, 1960). American Society for Testing Materials.

El-Shazly, E.M.,1958. A new meteorite record west of Aswan, Egypt. J. Geol., II (1), 71-72.

El-Sokkary, A.A.,1986. Field notes on the discovery of a new meteorite find in Kattamaiya Desert, south east of Cairo, Egypt. With photos of field of occurrence, meteorite big pieces and different specimens. Internal report, unpublished, NMA, Egypt.

Dana, E.S.,1949. A Text Book of Mineralogy. Pub. John Whiley and Sons, Inc.

Deer, W.A.; Howie, R.A., and Zussman, J.,1972. An Introduction to The Rock Forming Miner- als. Pub. Longman, London. 528p.

Heide, F.,1964. Meteorites. Pub. Science Series, Chicago Univ., Press. Chicago and London. 144p.

Mason, B. ,1964, Principles of Geochemistry. $2^{\text {nd }}$ Eidtion, Pub. John Wiley and Sons, Inc., New York. 310p.

Net site,2010. www.Google.com, Meteorites.

Urey, H.C., and Craig, H.,1953. The composition of the stone meteorites and the origin of the meteorites. Geochem. et Cosmochem. Acta, 4, 36-82.

Wedepohl, K.H.,1971. Geochemistry. Pub. Holt, Rinehart and Winston, Inc., New York. 231p.

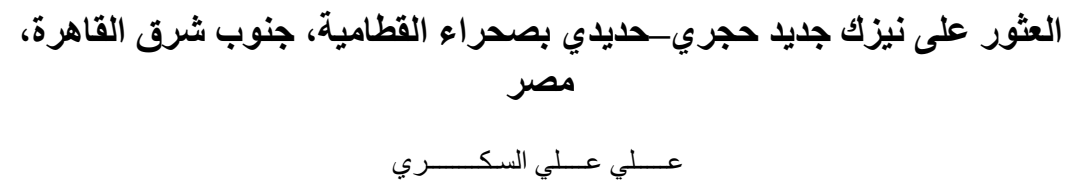

أكتشف و لأول مرة نيزك سماوي جديد يتو اجد بمنطقة صحر اء القطامية، جنوب شرق القاهرة بحو الي مسافة 25 كم القاء

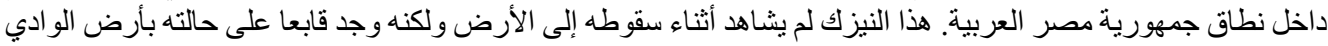

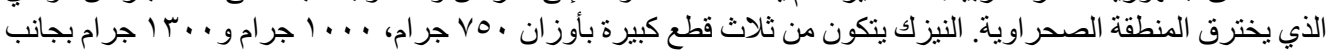

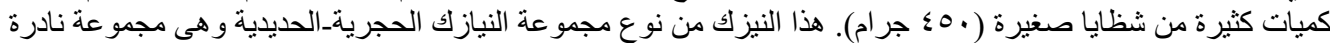

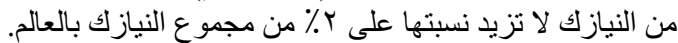

يتميز الوجه الحجري للنيزك بلون رمادي داكن أو لون أسود وهو مغطى بقشرة زجاجية خارجية، ملئ بالنقر أو الحفر

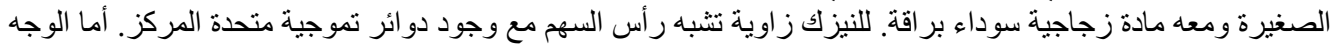

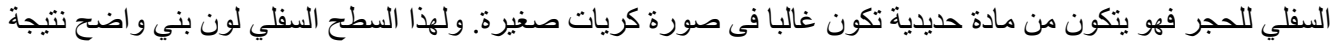

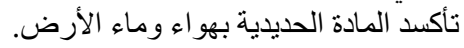

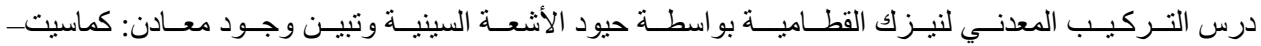

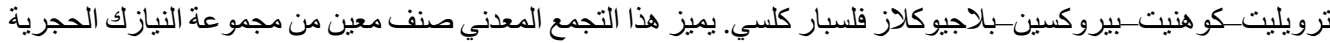
الحديدية يسمى ميزوسيدريتس.

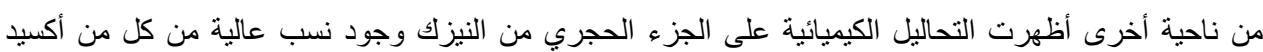

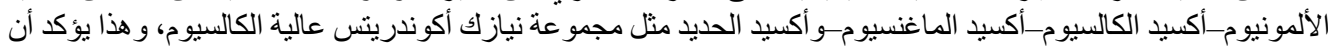

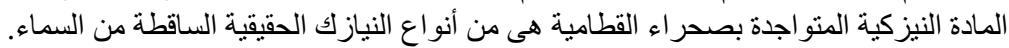

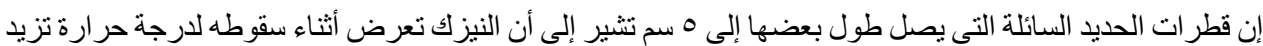

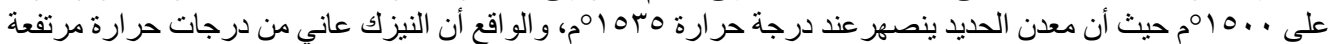

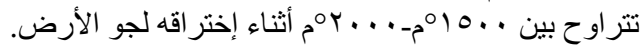

هكذا يشير مجمل الأدلة من الحقل ومن الوصف اليدوي للعينات ومشاهدة ما عليها من أنسجة كبيرة وتركيبات معدنية، 


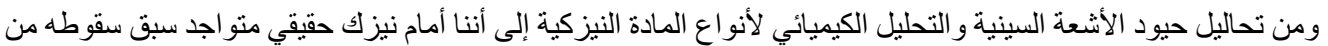

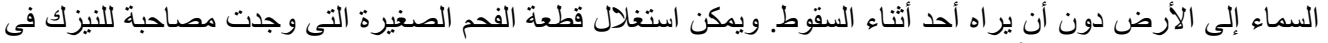

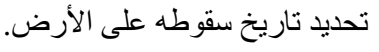

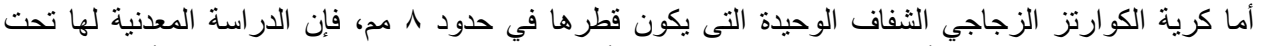

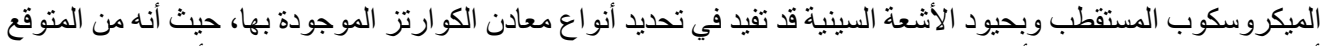

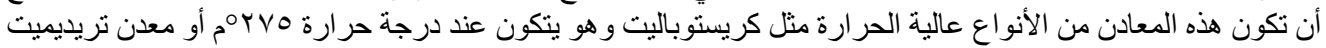

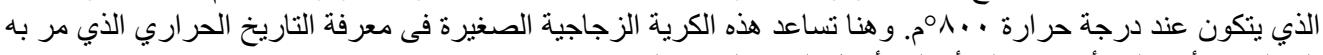

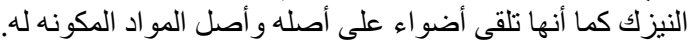

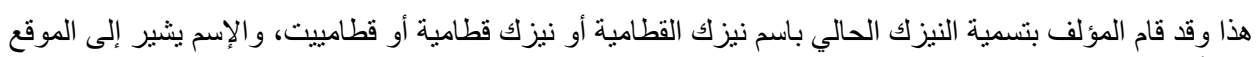
الأصلي الأول حيث وجدت هذه المادة النبزكية. 